\title{
Dynamic characteristics and fast load following of 5-kW class tubular solid oxide fuel cell/micro-gas turbine hybrid systems
}

\author{
Oh So-ryeok ${ }^{1, *, \dagger}$, Sun Jing ${ }^{2}$, Dobbs Herb ${ }^{3}$ and King Joel ${ }^{3}$ \\ ${ }^{1}$ University of Michigan, Naval Architecture and Marine Engineering, Michigan, USA \\ ${ }^{2}$ University of Michigan, Naval Architecture and Marine Engineering Department, Michigan, USA \\ ${ }^{3}$ US Army, TARDEC, Michigan, USA
}

\section{SUMMARY}

Combining solid oxide fuel cell and gas turbine (SOFC/GT) system is a promising concept for future clean and efficient power generation. An SOFC/GT system exploits the complementary features of the two power plants, where the GT recuperates the energy in the SOFC exhaust stream and thereby boosts the overall system efficiency. Through model-based transient analysis, however, it is shown that the intricate coupling dynamics make the transient load following very challenging. The purpose of this study is to examine the load-following capability of 5-kW class SOFC/micro-GT hybrid systems in two different configurations: single-shaft and dual-shaft GT designs. An optimal load-following operation scheme, aimed at achieving a proper trade-off between high steady-state efficiency and fast transient response is developed through model-based dynamic analysis and optimization. Simulation results are reported to illustrate the effectiveness of the proposed optimal scheme. Copyright @ 2013 John Wiley \& Sons, Ltd.

\section{KEY WORDS}

SOFC-GT; optimization; load following; thermal analysis

Correspondence

*Oh So-ryeok, University of Michigan, Naval Architecture and Marine Engineering, Michigan, USA.

†E-mail: srohum@umich.edu

Received 28 August 2012; Revised 17 January 2013; Accepted 20 January 2013

\section{INTRODUCTION}

As concerns regarding fossil energy sustainability and environmental impacts continue to grow, alternative power generation technologies have been explored to augment and improve the conventional energy conversion methods. In recent years, fuel cell technology has received increasing attention as one of the most promising alternative power systems for its high efficiency, low emissions and abundant fuel supplies [1], [2]. Unlike conventional batteries, fuel cells are able to keep working without a need to stop for charging, as long as fuel is supplied continuously. Potentially, fuel cells can have unlimited fuel sources if technology breakthroughs are achieved to produce hydrogen from water or many other sources efficiently and economically.

Solid oxide fuel cell (SOFC) technology is one of the most promising types of fuel cells currently being considered as clean and efficient power sources for mobile and stationary power plants [3]. To maintain the high oxide-ion conductivity of the solid oxide electrolyte, SOFCs must operate at a high temperature of 800-1000 ${ }^{\circ} \mathrm{C}$. This also provides SOFCs with another advantage, namely the high temperature of exhaust exiting an SOFC is perfectly suitable for the turbine inlet temperature (TIT) required by state-of-the-art turbomachinery. Therefore, an SOFC integrated with a gas turbine (GT) is being considered as an important technology to meet the requirements of future power generation. The GT not only provides the power needed to deliver required air flow for the SOFC, but also generates additional power from the waste heat of the high-temperature fuel cell stack.

Several different hybrid cycle arrangements have been studied by several groups in the past years [4]- [5]. Two distinct hybrid designs, topping and bottoming SOFC/GT systems, have been developed [6], [7]. The first design replaces the GT combustor directly with the fuel cell stack. This configuration results in the stack being pressurized at the operating pressure of the GT. The second system places the fuel cell stack at the exhaust of the GT. This 
configuration results in the fuel cell stack being operated slightly above atmospheric pressure. Additionally, it has been shown that the wide range of operation can be supported by burning residue and supplementary fuel in the afterburner. The studies show that the steady-state efficiency increases substantially for the integrated SOFC/ GT systems, compared to their standalone SOFC or GT modules [2]. An atmospheric SOFC/GT hybrid cycle was analyzed for design and part-load performance in [6] where two cases were investigated, namely the fixed-speed GT and variable-speed GT. Operating the GT at variable speed not only provides sufficient control of the SOFC temperature, but also increases the system efficiency.

Several experimental studies concerning SOFC/GT hybrid power plant test benches have been presented. A 250-kW SOFC/GT hybrid test facility has been operational at the National Energy Technology Laboratory, U.S. Department of Energy [8]. A fuel cell simulator, consisting of a natural gas burner and a real-time fuel cell model, has been integrated to mimic a real SOFC. The similar hybrid simulation facilities also have been constructed by other research groups [9], [10].

The system-level integration and optimization of the SOFC/GT power plants are important technology development aspects, as they determine the feasibility, reliability and effectiveness of this technology. To support the energy sustainability goals and make the SOFC/GT a competitive alternative technology to conventional power generation, the control systems and system integration strategies for SOFC/GT have to be addressed, in parallel with component innovation and development. The work reported in this paper focuses on the control issues of the hybrid power systems and seeks effective control designs to achieve robust and optimal operation of the SOFC/GT system.

Given that the high efficiency of the SOFC/GT is achieved by leveraging the close couplings among the two power plants, the interactions of the two systems become the dominant feature of this highly integrated system. More specifically, since the compressor is now driven by the turbine shaft instead of a standalone motor, the air delivery to the SOFC system is dictated by the turbine power, which in turn depends on the air delivered to the fuel cell. This interaction is the key for boosting system efficiency of the hybrid SOFC/GT system, but at the same time is also the root for causing some transient issues. Dynamic analysis of a planar SOFC/GT model has shown that the system is susceptible to power shutdown when an abrupt load increase is applied. The analysis of [11] revealed that the shutdown is initiated by the GT through the shaft dynamic coupling with the SOFC air supply system. Effectively managing the interactions for transient operation and steady-state operation is the main motivation of the work described in this paper.

The work reported here is built on relevant literature. Model-based analysis has been developed for SOFC/GT systems to support system design and control strategy design. The authors of [12] develop a dynamic model of an SOFC/GT system and evaluate the matching between that model and a linearized version of the same model. They note that the linear and nonlinear model responses match only for a small range of variations in the inputs, thereby concluding that the nonlinearities cannot be ignored in the model-based performance evaluation.

This paper is aimed at developing an optimal loadfollowing scheme for two distinct $5-\mathrm{kW}$ class SOFC/ micro-GT (mGT) designs: One is a single-shaft design with the compressor and turbine mounted on the same shaft as the power generator (GEN). Another is a dual-shaft design with two turbines, namely one drives a compressor and another is a free power turbine driving a GEN. To this end, dynamic models for the two configurations are developed first. Then, input sensitivity analysis is conducted to identify the dynamic mechanism responsible for the slow transient load responses of the developed $5-\mathrm{kW}$ class single- and dual-shaft SOFC/mGT hybrid systems. Finally, a mathematical framework for developing an optimal load-following strategy is proposed. The optimization formulation delineated in this paper allows the proper trade-off between the system efficiency and the fast load change capability by exploring the coupling between the SOFC/mGT load change and the SOFC temperature variations.

The remainder of this paper is organized as follows: the system operation principles are presented in Section II. SOFC and the mGT models are described in Sections III and IV, respectively. The load responses to a set of input parameter combinations are presented in Section V. The optimal strategy to achieve the fast load following is explained in Section VI, followed by conclusions.

\section{SYSTEM OPERATION PRINCIPLES}

SOFC-based power plants exhibit high efficiency and low emissions compared to conventional power production plants such as diesel or gasoline engines. In addition, other features enabled by the fuel cell technology, such as efficient electric power distribution, reconfigurability and silent operation make fuel cell power plants ideal candidates for military and commercial applications. Integrating fuel cell-based systems with energy recuperation devices can further improve the system's efficiency by reducing the exhaust energy losses. The hybrid SOFC/mGT system analyzed in this work is particularly designed as an auxiliary power unit (APU) targeting military and commercial applications. For example, this unit can be employed in a commercial vehicle for power production during stops to avoid idling of the main engine and to improve efficiency. For military trucks, the proposed APU can provide sufficient power to support silent watch and other missions without involving the main engine. The system has a rated power of around $5 \mathrm{~kW}$.

The key system components include an SOFC stack, a compressor, a catalytic burner (CB), micro-turbines which drives a GEN. Other components, such as the reformer and 
the heat exchangers, are not included in this work in order to focus on the coupling dynamics between the SOFC and the mGT, as shown in Figure 1(a) for a single-shaft GT. The schematics of the system are shown in Figure 1(b) for a dual-shaft system.

The air to the SOFC is supplied to the cathode side by a compressor, while pre-reformed fuel is fed to the anode side. The exhaust from the SOFC outlet passes through the $\mathrm{CB}$ where the unused fuel is burned to increase the temperature and pressure of the flow. The high-temperature and high-pressure flow from the $\mathrm{CB}$ then powers the turbine, thereby providing a mechanism to recuperate the exhaust energy. In the single-shaft design (Figure 1(a)) the turbine drives both the compressor and the GEN through a mechanical shaft; the former delivers the air needed for the SOFC stack operation, and the latter provides additional electrical power for the system. The net power output is the sum of the electric power from the SOFC and the GEN. On the other hand, in the splitshaft design (Figure 1(b)), there are two turbines. One is a gasifier turbine driving a compressor and another is a free power turbine driving a GEN. Since these two turbines have no mechanical coupling, the design can offer better flexibility for the compressor and the power turbine/GEN operation. The modeling of the plant components is presented in the following section.

\section{SOFC MODEL DESCRIPTION}

\subsection{Tubular SOFC model}

In a tubular design, air is supplied to the inside of the tube and fuel to the outside (see Figure 2). Air enters the feed

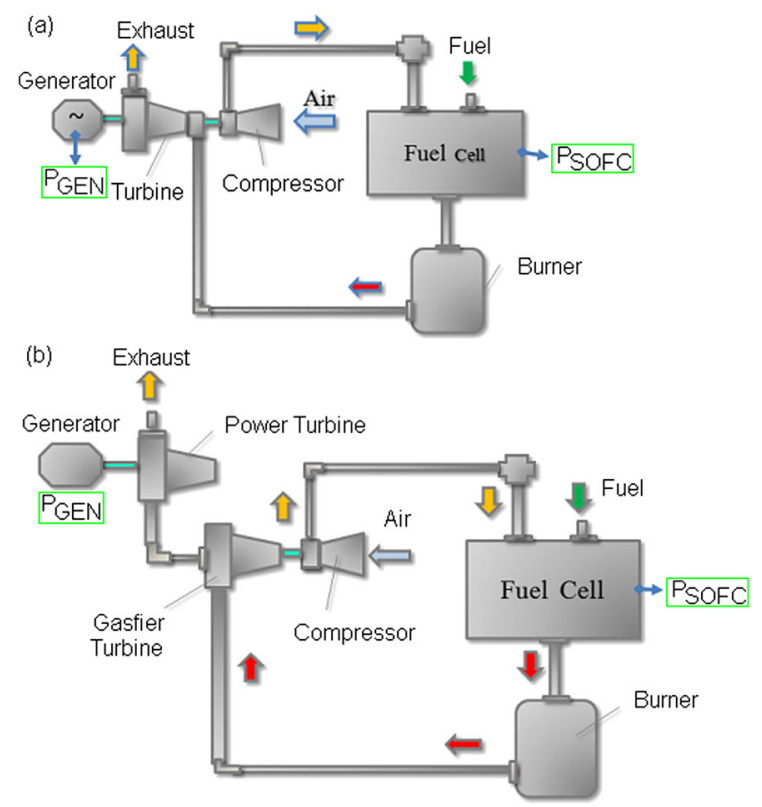

Figure 1. SOFC/GT hybrid schematic: single shaft (a) and dual shaft (b)

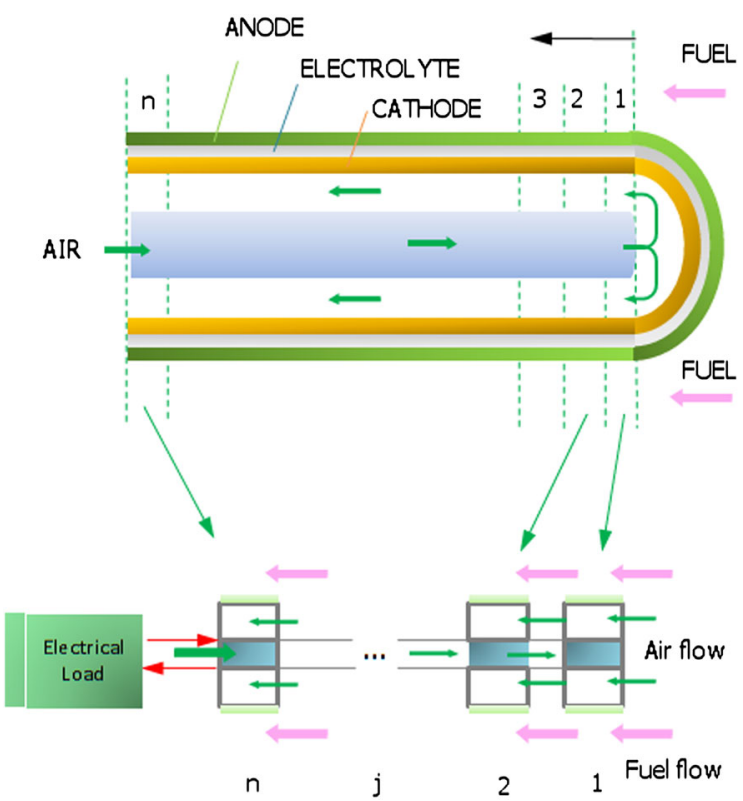

Figure 2. Finite volume discretization for a tubular SOFC.

tube at the bottom and travels to the closed end of the cell at the top. Fuel enters on the outside at the closed end. The air and fuel both flow along the cell in the same direction from the closed end toward the open end, giving a co-flow configuration.

An SOFC model is developed using mass balance and energy balance. The following main assumptions are made to take into account the trade-off between acceptable computational load and sufficient model accuracy:

1) The anode, cathode and electrolyte are treated as one single entity.

2) The SOFC can be treated as a distributed parameter system in order to capture the spatial distribution along the flow field for variables such as temperature, species concentration and current density.

3) All gases are assumed to be ideal.

4) All cells in the stack are assumed to operate identically.

5) Compressor flow, pressure and power characteristics are modeled using performance maps [11].

6) $\mathrm{N}_{2}, \mathrm{H}_{2}, \mathrm{CH}_{4}, \mathrm{H}_{2} \mathrm{O}, \mathrm{CO}$ and $\mathrm{CO}_{2}$ are assumed to be the species in the flow through the fuel channel and $\mathrm{N}_{2}, \mathrm{O}_{2}$ through the air channel.

\subsubsection{Electrochemical model}

The operating voltage of one discretization unit of the cell can be calculated as follows:

$$
U_{j}=U_{O C V}^{j}-\left(\eta_{o h m}^{j}+\eta_{a c t}^{j}+\eta_{c o n}^{j}\right), j=1,2, \cdots, n,
$$

where $j$ is the index of discretization units, as shown in 
Figure 2. $U_{O C V}^{j}$ is the open-circuit voltage in the $j$ th unit. For simplicity, the notation $j$ will be omitted in the rest of equations. The open-circuit voltage can be determined by the Nernst Equations ([13], [15]) as follows

$$
U_{O C V}=E_{0}-\frac{\widetilde{R} T_{P E N}}{2 F} \ln \frac{p_{\mathrm{H}_{2} \mathrm{O}}}{p_{\mathrm{H}_{2}} p_{\mathrm{O}_{2}}^{0.5}}
$$

with $E_{0}=1.2723-2.7645 \times 10^{-4} T_{P E N}$, where $T_{P E N}$ is the temperature of the Positive Electrode Electrolyte Negative Electrode (PEN) structure, and $p_{\mathrm{H}_{2} \mathrm{O}}, p_{\mathrm{H}_{2}}$ and $p_{\mathrm{O}_{2}}$ are the partial pressures of $\mathrm{H}_{2} \mathrm{O}, \mathrm{H}_{2}$ and $\mathrm{O}_{2}$, respectively. The last three terms in (fFCM0) represents various potential losses: The activation loss, $\eta_{a c t}$, is due to the energy barriers to be overcome in order for the electrochemical reaction to occur and can be characterized by the Butler-Volmer equation. The concentration loss, $\eta_{\text {con }}$, reflects the overpotential due to the species diffusion between the reaction site and the bulk flow in gas channels, and $\eta_{\text {ohm }}$ is the ohmic loss due to the electrical and ionic resistance along the path of the current in the fuel cell. The ohmic, activation and concentration polarization are calculated according to the procedure discussed in [13].

\subsubsection{Mass balances}

For the mass balance in the fuel channel, the chemical species considered are $\mathrm{CH}_{4}, \mathrm{H}_{2} \mathrm{O}, \mathrm{CO}, \mathrm{CO}_{2}, \mathrm{H}_{2}$ and $\mathrm{N}_{2}$, while for the air channel, the chemical species are $\mathrm{O}_{2}$ and $N_{2}$. Table I presents the fuel and air channel mass balance equation. In the fuel channel, three reactions are taken into account: methane steam reforming (SR), water gas-shift (WGS) and hydrogen electrochemical oxidation (Ox). In the air channel, only the reduction reaction of $\mathrm{O}_{2}$ to $\mathrm{O}^{2-}$ ions is considered (Red). Table II lists all these reactions. According to Faraday's law, the rates of Ox and Red reactions are related to the current density as follows:

Table I. Dynamic SOFC model: mass balance equations.

Fuel channel
$\dot{C}_{i, f}=\left(\mathrm{N}_{\text {in }, f, i}-\mathrm{N}_{\text {out }, \mathrm{f}, \mathrm{i}}\right) \frac{1}{V_{t}}+\sum_{k \in\{\mathrm{SR}, \mathrm{WGS}, \mathrm{Ox}\}} v_{i, k} r_{k} \frac{1}{d_{t}}$
$\mathrm{i} \in\left\{\mathrm{CH}_{4}, \mathrm{CO}_{2}, \mathrm{CO}, \mathrm{H}_{2} \mathrm{O}, \mathrm{H}_{2}, \mathrm{~N}_{2}\right\}$
Air channel
$\dot{C}_{i, a}=\left(\mathrm{N}_{\mathrm{in}, \mathrm{a}, \mathrm{i}}-\mathrm{N}_{\text {out }, \mathrm{a}, \mathrm{i}}\right) \frac{1}{V_{a}}+\sum_{k \in\{\text { Red }\}} v_{i, k} r_{k} \frac{1}{d_{a}}$
$\mathrm{i} \in\left\{\mathrm{O}_{2}, \mathrm{~N}_{2}\right\}$

Table II. Reactions considered in the model.

\begin{tabular}{lll}
\hline \multicolumn{1}{c}{ Location } & Reaction & \multicolumn{1}{c}{ Expression } \\
\hline Fuel channel & $\mathrm{SR}$ & $\mathrm{CH}_{4}+\mathrm{H}_{2} \mathrm{O} \rightarrow \mathrm{CO}+3 \mathrm{H}_{2}$ \\
& WGS & $\mathrm{CO}+\mathrm{H}_{2} \mathrm{O} \rightarrow \mathrm{CO}_{2}+\mathrm{H}_{2}$ \\
Anode & $\mathrm{Ox}$ & $\mathrm{H}_{2}+\mathrm{O}^{2-} \rightarrow \mathrm{H}_{2} \mathrm{O}+2 \mathrm{e}^{-}$ \\
Cathode & Red & $0.5 \mathrm{O}_{2}+2 \mathrm{e}^{-} \rightarrow \mathrm{O}^{2-}$ \\
\hline
\end{tabular}

$$
r_{O x}=r_{R e d}=\frac{i}{2 F}
$$

The SR reaction is slow and highly endothermic, while the WGS is fast and weakly exothermic. Thus, the entire reforming process is dominated by the endothermic SR reforming reaction that requires the heat generated by the electrochemical reaction. In this study, the model proposed by [13]-[14] is adopted for the reaction rate of the fuel reforming reaction, namely:

$$
r_{S R}=0.04274 \cdot p_{C H_{4}} \cdot \exp \left(-\frac{E_{S R}}{\widetilde{R} T_{f}}\right),
$$

with $E_{S R}=82 \mathrm{kJmol}^{-1}$. The following reaction rate for WGS, given in [16], is adopted, where $k_{W G S}$ assumes large value, reflecting the very fast kinetics of the WGS reaction with $K_{e q, W G S}=\exp \left(4276 / T_{f}-3.961\right)$.

$$
r_{W G S}=k_{W G S} \cdot p_{C O} \cdot\left(1-\frac{p_{\mathrm{CO}_{2}} p_{\mathrm{H}_{2}}}{p_{\mathrm{CO}} p_{\mathrm{H}_{2} \mathrm{O}} K_{e q, W G S}}\right) .
$$

\subsubsection{Energy balances}

The temperatures in five layers, i.e. the fuel/air bulk flow $\left(T_{f} / T_{a}\right)$, PEN structure $\left(T_{P E N}\right)$ and the feed tube/air $\left(T_{I}, T_{I a}\right)$, are calculated by solving the dynamic equations of the energy balance in each layer. The energy balance dynamics are listed in Table III. Right-hand side terms in the equations are composed of rate of energy entering/ leaving a control volume by inflow/outflow and rate of

Table III. Dynamic SOFC model: energy balances.

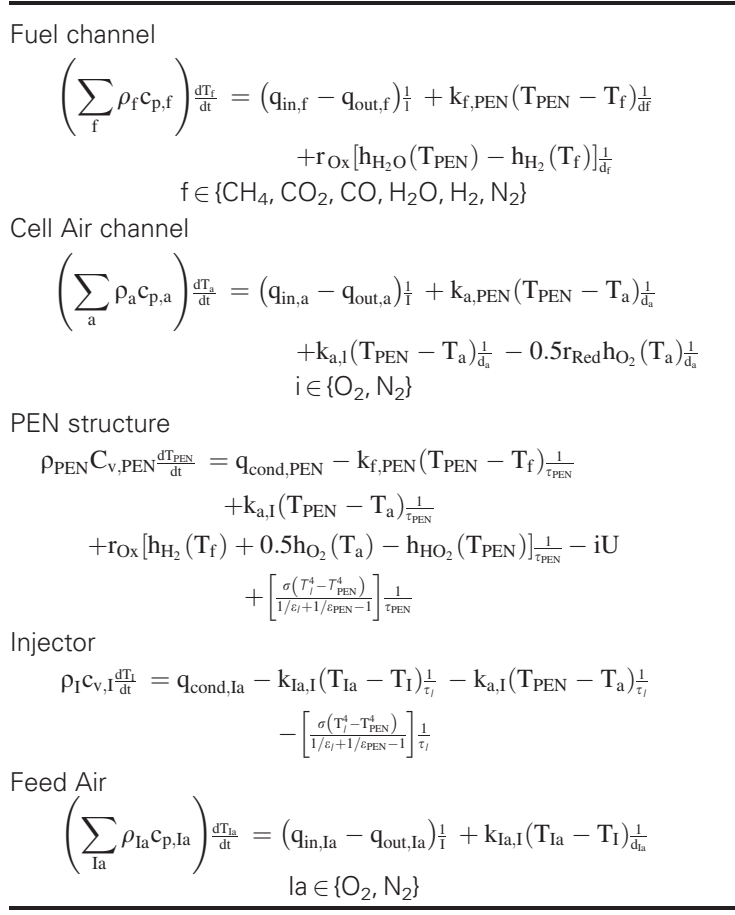


heat added/dissipated through both chemical reaction and heat transfer. The heat transfer processes include heat release arising from the chemical and electrochemical reactions and electrical resistances; convective heat transfer between cell components and fuel and air gas streams; and heat conduction through cell components; radiation heat exchange between the PEN and an air feed tube.

\subsection{Dynamic simulation and model validation}

A tubular SOFC model was implemented in Matlab/ Simulink environment. The model is used to calculate the various temperatures along the flow path, the gas composition in the fuel and air channel, all the electrochemical-related variables (open-circuit voltage, current density) as well as the cell efficiency and power output. The cell parameters, such as operating conditions and the physical property values of the cell materials and geometry, have been taken from the literature [17], teHanda. The simulations were conducted under the following conditions: the cell inlet temperature is $1000 \mathrm{~K}$, fuel utilization is set to $85 \%$, and air has a stoichiometric ratio of 4 . Figure 3 (a) shows the results of different temperature profiles for the fuel and air channels, PEN structure and injector, along the cell length. It can be seen that the cell temperature increases along the fuel and air flow directions with the maximum temperature occurring near the outlet. Figure 3(b) presents the mole fraction profiles in the fuel channel stream. These illustrate the impact of the simultaneous occurrence of the direct internal reforming reaction, the WGS reaction and the Ox of hydrogen at the anode-electrolyte interface. The consumption of hydrogen and the production of steam can be clearly identified along the cell length as the hydrogen Ox reaction proceeds. At the exit of the fuel channel, all the methane has been fully consumed, and the stream content is $33 \%$ in $\mathrm{H}_{2} \mathrm{O}, 4 \%$ in $\mathrm{CO}, 6 \%$ in $\mathrm{H}_{2}$ and $16 \%$ in $\mathrm{CO}_{2}$.

Figure 4 presents the characteristic curves of cell voltage and power density as a function of current density. In Figure 4(a), the simulation results are compared to the actual test data taken from [3] for voltage and power output for different current density. This comparison shows a good match between the simulation model and the test data
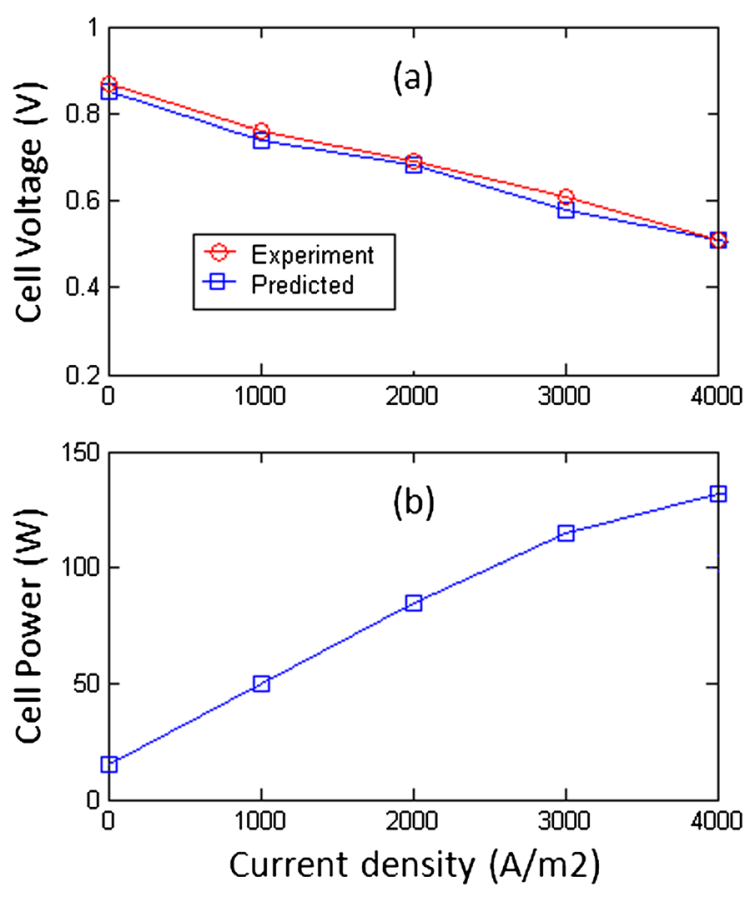

Figure 4. (a) Fuel and air channels, PEN structure and injection tube temperature along the cell length. (b) Fuel channel component mole fraction along the cell length.

(presented in literature) as the percent error between the model prediction and experimental test data is less than $3 \%$ over the experimentally verified current density range.

In order to combine the tubular SOFC with a GT cycle, the nominal cell operation point has been selected to match the GT system. The cell operating point is often designed to be where the ohmic resistance has a dominant influence. For this tubular SOFC system, this corresponds to a voltage range of $0.6-0.7 \mathrm{~V}$. With this voltage range, an average current density of $2000 \mathrm{~A} / \mathrm{m}^{2}$ and a single cell power of $90 \mathrm{~W}$ have been calculated from the cell current power profile shown in Figure 4(b). The stack was chosen to have 60 cells in order to produce a rated power of $5.4 \mathrm{~kW}$. We then chose the fuel flow for the tubular SOFC model to meet the average current density and $85 \%$ fuel utilization

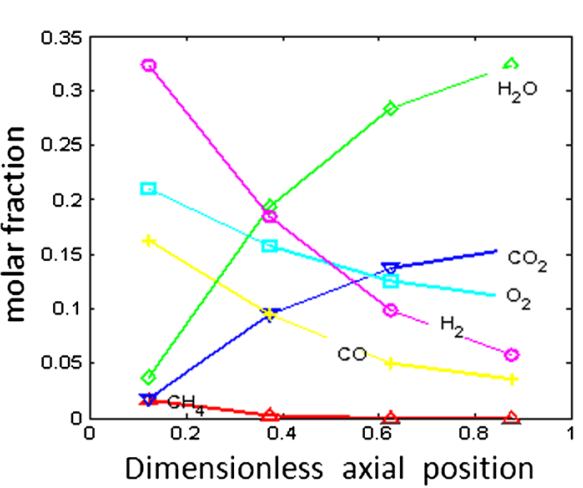

Figure 3. (a) Fuel and air channels, PEN structure, and injection tube temperature along the cell length. (b) Fuel channel component mole fraction along the cell length. 
requirements. In addition, the tubular system is known for operating with lower air excess ratios due to the ability of the tubes in tolerating thermal gradients [18]. Hence, a relatively low air excess of 4 was chosen for the SOFC operation. The key cell operation variables at the design point are summarized in Table IV.

\section{MGT MODELS FOR SINGLE AND DUAL-SHAFT SYSTEMS}

This section describes the modeling work on the turbomachinery part of the two SOFC/mGT hybrid systems in singleand dual-shaft configurations. The SOFC nominal operating conditions shown in Table IV are used as a baseline model for the matched design of the SOFC and the mGT.

\subsection{Single-shaft mGT}

The mGT model incorporates the shaft rotational speed dynamics, the compressor and the turbine sub-models. The performance data used in this study is specified in the form of compressor and turbine maps [19], which present absolute values for a specific compressor. Since no map of commercially available turbines matched the specifications of the mass flow and pressure ratios required by the

Table IV. Design point data of the tubular SOFC.

\begin{tabular}{lll}
\hline \multicolumn{1}{c}{ Parameter } & \multicolumn{1}{c}{ Value } & \multicolumn{1}{c}{ Comments } \\
\hline Cell power & $90[\mathrm{~W}]$ & $\begin{array}{l}\text { Single Cell Power: } 90[\mathrm{~W}] \\
\text { Cell Number: } 60 \\
\text { Total Stack Power: } 5.4[\mathrm{~kW}]\end{array}$ \\
Voltage & $0.67[\mathrm{~V}]$ & \\
Current density & $2000\left[\mathrm{~A} / \mathrm{m}^{2}\right]$ & \\
FU & $85 \%$ & \\
Air excess ratio & 4 & \\
Fuel flow & $0.099[\mathrm{~kg} / \mathrm{s}]$ & $0.002[\mathrm{~mol} / \mathrm{s}]$ \\
Air flow & $0.44[\mathrm{~kg} / \mathrm{s}]$ & $0.012[\mathrm{~mol} / \mathrm{s}]$ \\
\hline
\end{tabular}

Dimensionless pressure ratio

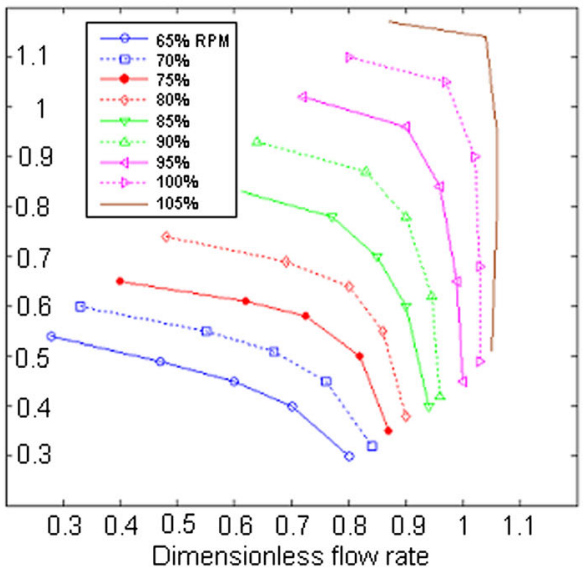

SOFC/mGT under investigation, the maps used in this modeling work, shown in Figure 5, were derived by normalization and proper scaling. The main variables used in those models include pressure $p$, flow $\dot{m}$, temperature $T$ and power $P$. Note that the subscripts denote the component (c for compressor and t for turbine) and the inlet or outlet ( 1 or 2 , respectively). For example, $p_{c 2}$ denotes the outlet temperature of the compressor.

These compressor and turbine maps provide steadystate mass flow, pressure ratio and efficiency as a function of rotational speed. The mass flow can be calculated from the performance maps for any given rotational speed and pressure ratio. Once the mass flow is determined, a compressor efficiency can be determined from the efficiency map. Knowing the isentropic efficiency, the compressor exit temperature can be determined from the isentropic relations described as follows:

$$
T_{C 2}=T_{C 1}\left\{1+\frac{1}{\eta_{c o m p}}\left[\left(\frac{p_{c 2}}{p_{c 1}}\right)^{\frac{\gamma-1}{\gamma}}-1\right]\right\} .
$$

The power $\mathrm{P}_{c}$ required to drive the compressor can be related to the mass flow rate $\dot{m}_{c}$ and the enthalpy change across the compressor from the first law of thermodynamics as

$$
P_{c}=\dot{m}_{c}\left(h_{c 2}-h_{c 1}\right) \text {. }
$$

Assuming that the specific heat coefficients of air do not change, we have

$$
P_{c}=\dot{m}_{c} c_{p \mid c\left(T_{c 2}-T_{c 1}\right)}
$$

The turbine model is constructed in a similar way as the compressor. The turbine/GEN rotational dynamics are determined by the power generated by the turbine $P_{t}$, the power required to drive the compressor $P_{c}$ and the power drawn by the GEN $P_{G E N}$ as:

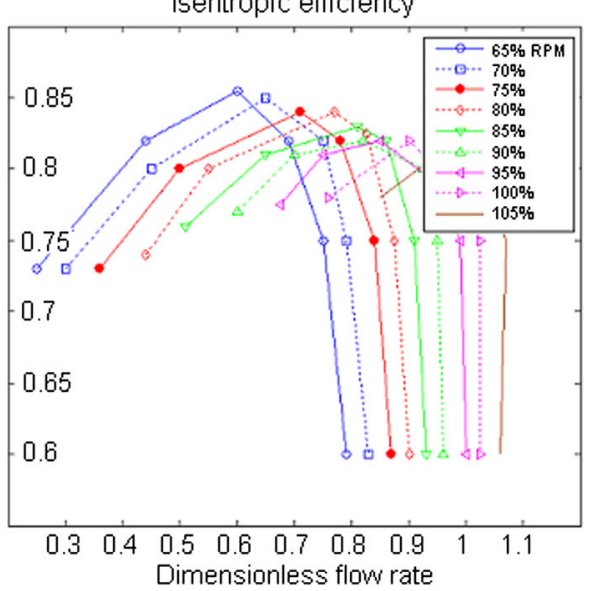

Figure 5. Normalized performance map for a compressor. It is based on a generic map from [17]. 


$$
\frac{d N}{d t}=\frac{P_{t} \eta_{m}-P_{c}-P_{g e n}}{\alpha \cdot N \cdot J}
$$

where $N$ is the turbine speed in revolutions per minute (rpm) and $\eta_{m}$ is the turbine mechanical efficiency that accounts for energy losses due to friction. The turbocharger inertia is considered constant and equal to a typical value of 0.95 . The turbocharger inertia $J$ is the sum of rotor inertia, compressor inertia and turbine wheel inertia about the axis of rotation. The factor $\alpha=(2 \pi / 60)^{2}$ is a result of converting the speed from rad/s to rpm.

In addition, in modeling the $\mathrm{CB}$, the mass/temperature dynamics used in [11] are taken into account as follows:

$$
\begin{gathered}
\frac{d m_{c b}}{d t}=\dot{m}_{c a}+\dot{m}_{a n}-\dot{m}_{t} \\
m_{c b} c_{p, c b} \frac{d T_{c b}}{d t}=\sum_{i=1}^{n} N_{i, c b}^{I n} h_{i, c b}^{I n}-\sum_{i=1}^{n} N_{i, c b}^{\text {Out }} h_{i, c b}^{\text {Out }}
\end{gathered}
$$

where $\dot{m}_{c a}, \dot{m}_{a n}$ are the anode and cathode outlet mass flows, respectively, and $\dot{m}_{t}$ is the flow through the turbine. $h_{i, c b}^{I n}, \quad h_{i, c b}^{\text {Out }}$ are the inlet and outlet enthalpies of the gas species $i$, and $N_{i, c b}^{I n}, N_{i, c b}^{O u t}$ are the associated molar flow rates. Adiabatic boundaries are assumed for the cell, $\mathrm{CB}$, and turbine (i.e. no heat losses from the SOFC, $\mathrm{CB}$ and turbine walls to the environment).

\subsection{Dual-shaft mGT}

The model for the dual-shaft system is developed following the same modeling guidelines used for the single-shaft design. The dual-shaft turbine maps are resized properly so that the dual-shaft turbine power matches that of the singleshaft system at the design point. The same equations are used to calculate the inlet/outlet temperatures and enthalpies for the twin-shaft mGT modeling. The rotor dynamics of gas and power turbines are modeled as in (12) and (13), respectively,

$$
\begin{gathered}
\frac{d N_{1}}{d t}=\frac{P_{t, 1} \eta_{m, 1}-P_{c}}{\alpha \cdot N_{1} \cdot J_{1}}, \\
\frac{d N_{2}}{d t}=\frac{P_{t, 2}-b N_{2}^{2}-P_{G E N}}{\alpha \cdot N_{2} \cdot J_{2}},
\end{gathered}
$$

where $b$ is the friction coefficient of the power turbine. Contrary to (12), the damping effect due to the mechanical friction is represented in a separate form $\left(b N_{2}^{2}\right)$ which yields a stable damped response of the power turbine. Since these two turbines have no mechanical coupling, the design offers flexibility in operating the compressor and the GEN at different speed to achieve optimal efficiency.

\section{ANALYSIS OF LOAD TRANSIENT CHARACTERISTICS}

The operation of $\mathrm{SOFC} / \mathrm{mGT}$ plants is dictated by three different control inputs, namely the fuel flow $\left(W_{F u e l}\right)$, the current density $\left(I_{C O M}\right)$ and the GEN load $\left(P_{G E N}\right)$.

For a given fuel flow, different combinations of current drawn from the SOFC and load applied to the GEN will yield different net power. In order to determine the maximum steady-state net power output for a given fuel flow, the following optimization problem is solved,

$$
\max _{I_{\text {com }}, P_{G E N}} \eta_{S O F C / G T}
$$

By repeating the optimization problem for different fuel flows, the optimal steady-state operation points are obtained, which provides the current density from the SOFC unit, the required fuel flow and the power delivered by the GEN as functions of the net power generated by the integrated system. The results can be easily implemented with a look-up table and used as static feedforward maps to schedule the actuators and power split to achieve the maximum steady-state efficiency for different power demands. The detailed descriptions of computing the operating maps were reported in [20].

Since there exist multiple ways of achieving a prescribed power generation target, different combinations lead to different steady-state efficiency as well as different transient behavior. This study attempts to investigate the dynamic behavior of the system during transients, with the objective of leveraging the flexibility offered by the multiple control design degrees of freedom to achieve fast and safe load-following operation. Towards this end, we analyze several typical transient operation scenarios for both the single and dual-shaft systems to identify the key characteristics that can be exploited.

\subsection{Single-shaft SOFC/mGT case}

We consider a typical step load transient operation from $5.0 \mathrm{~kW}$ to $5.5 \mathrm{~kW}$. The optimal input settings for these two power levels, which yield the highest system efficiency, are $\left(W_{\text {fuel }}, I_{C O M}, P_{G E N}\right)=\left(1.8 e^{-3} \mathrm{~kg} / \mathrm{s}, 1800 \mathrm{~A} / \mathrm{m}^{2}, 300 \mathrm{~W}\right)$, and $\left(2.10 e^{-3} \mathrm{~kg} / \mathrm{s}, 1850 \mathrm{~A} / \mathrm{m}^{2}, 560 \mathrm{~W}\right)$, respectively. We consider four different input combinations that all achieve the same SOFC/mGT power output. These inputs are shown in Table $\mathrm{V}$, and their corresponding responses are given in Figure 6. The last column in Table $\mathrm{V}$ also gives the system efficiency for different control input combinations.

The results show that using both the fuel and SOFC current inputs (Nos. 2-4) can enhance system efficiency as compared to the case of using only the fuel (No. 1). The difference in part-load efficiency for No. 1 and No. 4 can be as much as $3.6 \%$. It can be observed from Figure 6 that the net output power slowly converges to the steadystate value over time, and the settling time can be as long as $1000 \mathrm{~s}$ where the settling time is defined as the time 
Table V. Load change scenario: single-shaft hybrid model.

\begin{tabular}{|c|c|c|c|c|}
\hline No & $W_{\text {Fuel }}$ & $I_{C O M}$ & $P_{G E N}$ & $\eta$ \\
\hline 1 & $2.0 e^{-3}+\Delta W_{100 \%}$ & $2000+\Delta I_{0} \%$ & 560 & $37.8 \%$ \\
\hline 2 & $2.0 e^{-3}+\Delta W_{75} \%$ & $2000+\Delta / 50 \%$ & 560 & $38.4 \%$ \\
\hline 3 & $2.0 e^{-3}+\Delta W_{50} \%$ & $2000+\Delta / 81 \%$ & 560 & $39.4 \%$ \\
\hline $\begin{array}{l}4 \\
\text { whe }\end{array}$ & $\begin{array}{c}2.0 e^{-3}+\Delta W_{25} \% \\
{ }^{4} \mathrm{~kg} / \mathrm{s}, \Delta / 100 \%=16\end{array}$ & $2000+\Delta I_{100} \%$ & 560 & $41.4 \%$ \\
\hline
\end{tabular}
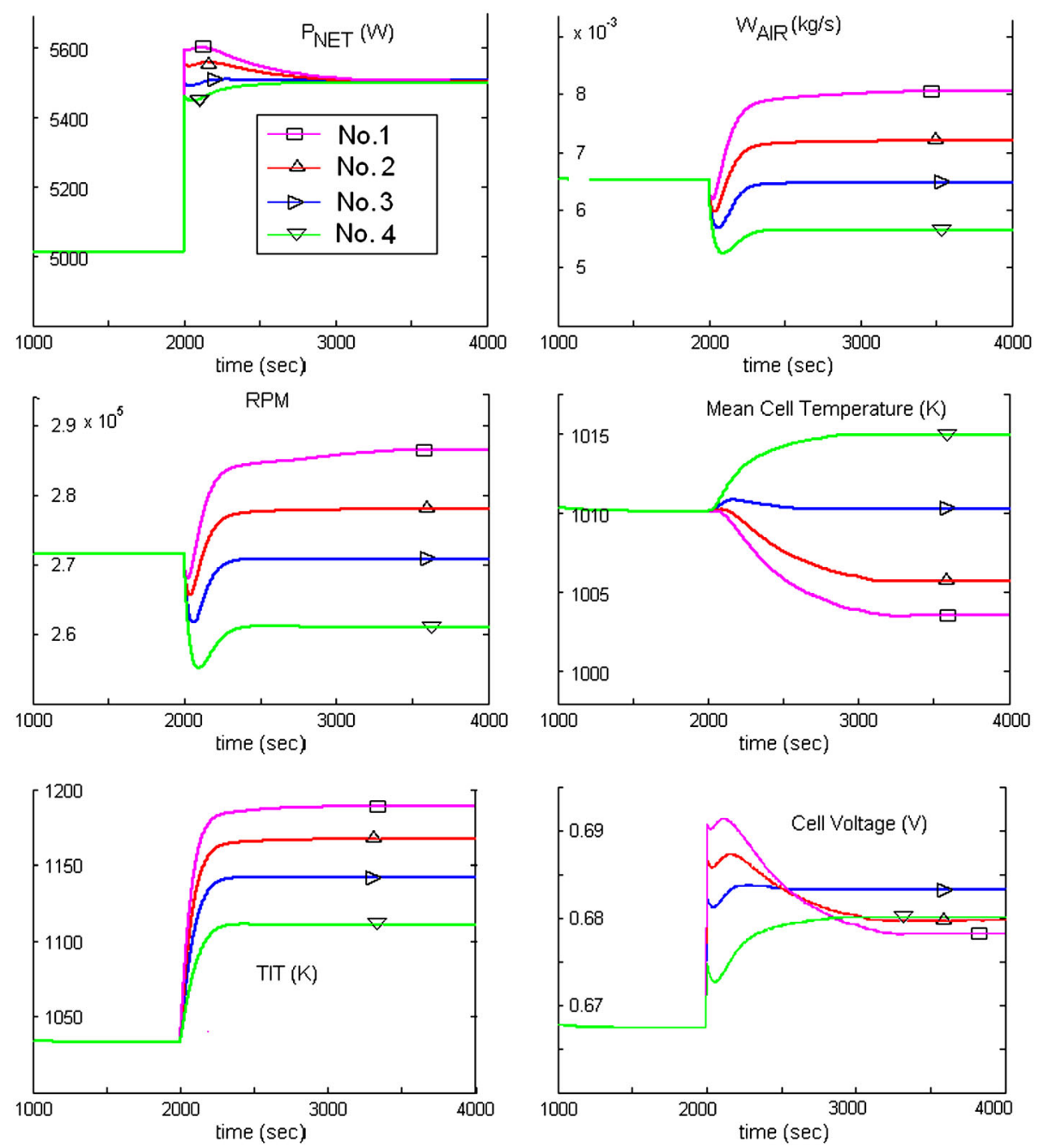

Figure 6. The power responses of single-shaft SOFC/mGT under various combinations of control inputs given in Table V.

period required to reach $98 \%$ of a target power. This slow response is largely due to the thermal inertia of the fuel cell. This can be confirmed by the fact that the response of the power output is closely correlated to that of the fuel cell temperature. In addition, as $\Delta W_{\%}\left(t_{a} I_{\%}\right)$ decreases (increases), the power overshoot decreases. This indicates that an excessive overshoot in the power profile can be prevented by properly allocating the control effort to two independent controls rather than using $W_{\text {Fuel }}$ alone. Note that the steady-state cell temperature increases as $\Delta W_{\%}$ decreases, while the TIT following an opposite trend. This is partly due to the diminished cooling effects of reduced air intake (responsible for reduced cell temperature) and reduced lower fuel utilization in SOFC and higher heat release in the CB (responsible for the higher TIT).

Another important transient feature observed in this analysis is that the fast load transient corresponds to the control combination that maintains the mean PEN (the anode/ 
electrolyte/cathode layers) temperature almost as constant over the transition period (see the cell mean temperature in Figure 6). This indicates that a well-coordinated control which can achieve the target power while avoiding large temperature change of the fuel cell will have a major advantage in transient performance. The given load-following objective can also be achieved by keeping a constant TIT or the shaft speed, N, (see TIT/N plot in Figure 6).

This analysis leads to important insights and will be used as guidelines for future control design.

\subsection{Dual-shaft SOFC/mGT case}

The analysis was also performed for the dual-shaft hybrid SOFC/mGT system model for the same step load change $(5.0 \mathrm{~kW}$ to $5.5 \mathrm{~kW})$ as applied to the single-shaft SOFC/ mGT model. The results shown in Figures 7 and 8 and Table VI reveal the fact that the cell mean temperature can be maintained constant during the load operation under the coordination of $W_{\text {Fuel }}$ and $I_{C O M}\left(\right.$ Nos. 1-3) as well as $W_{\text {Fuel }}$ and $P_{G E N}$ (Nos. 4-6). We note that the settling times of the dual-shaft design are much longer than that for its singleshaft counterpart ( $1600 \mathrm{~s}$ vs $1000 \mathrm{~s}$ ). This is because the twin-spool design requires drawing more current from the SOFC stack to produce the same amount of the power than that of the single-spool system due to its low power split ratio [20], namely large quantities of heat with high thermal inertia is released from the SOFC stack, which is prone to increase the transit time in the dual-shaft case. Using the combination of fuel and SOFC current control (Nos. 1-3) exhibits transient responses similar to the combination of fuel and GEN load control (Nos. 4-6). The system steady-state efficiencies for different operating strategies are shown in Table VI. Overall efficiencies are slightly lower than those of the single-shaft design. This is partly due to irreversible effects such as mechanical frictions of gas and power turbines: A mechanical efficiency of $\eta_{m}=95 \%$ has been applied to each shaft dynamics. Note that the definitions of the $100 \%$ control variations are $\Delta P_{G E N, 100 \%}=43 \mathrm{~W}, \Delta I_{100 \%}=60 \mathrm{~A} / \mathrm{m}^{2}$ and $\Delta W_{100 \%}=2.0 e^{-4} \mathrm{~kg} / \mathrm{s}$.
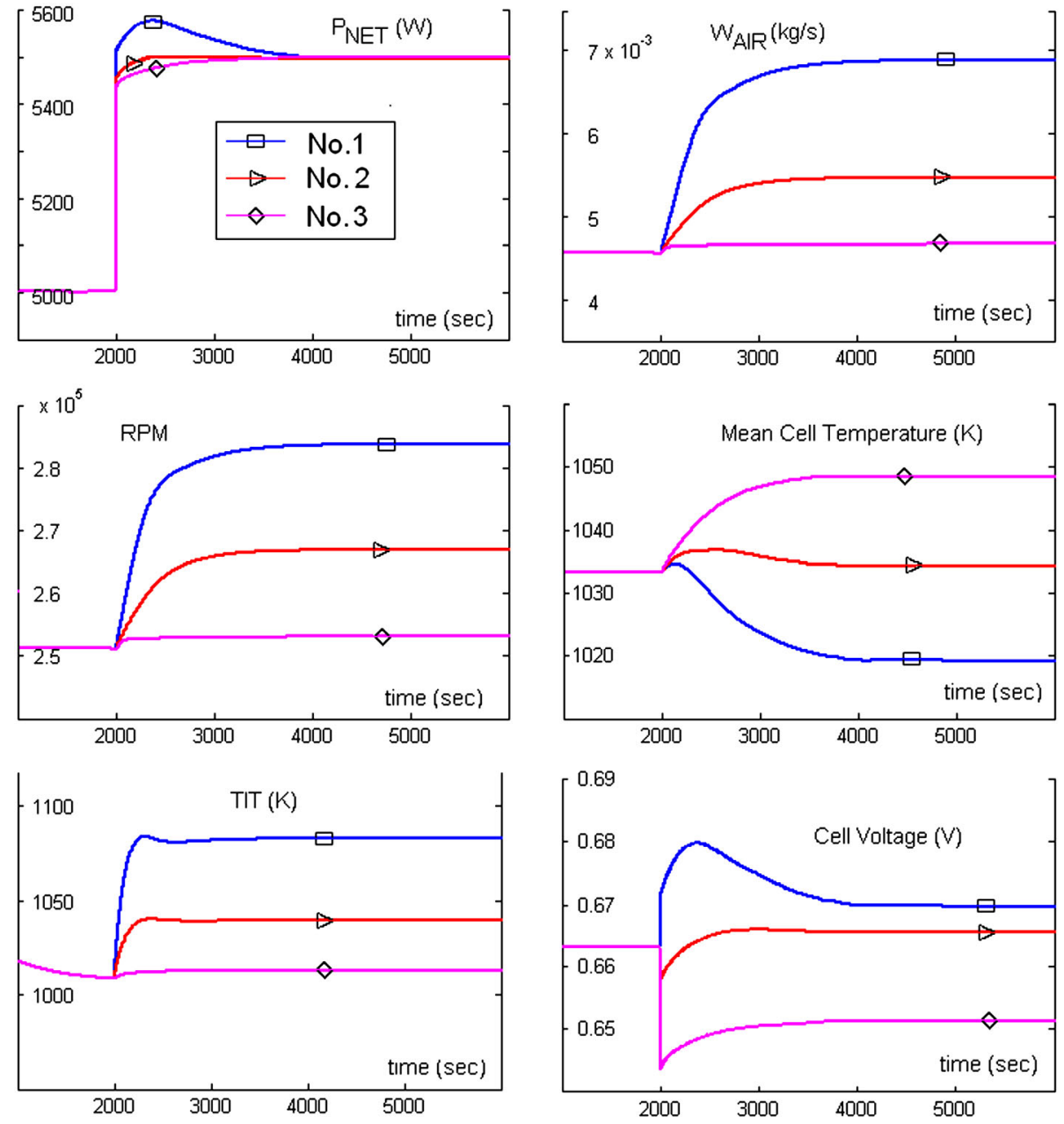

Figure 7. The power responses of dual-shaft SOFC/GT under control input combinations (Nos. 1-3) in Table VI. 

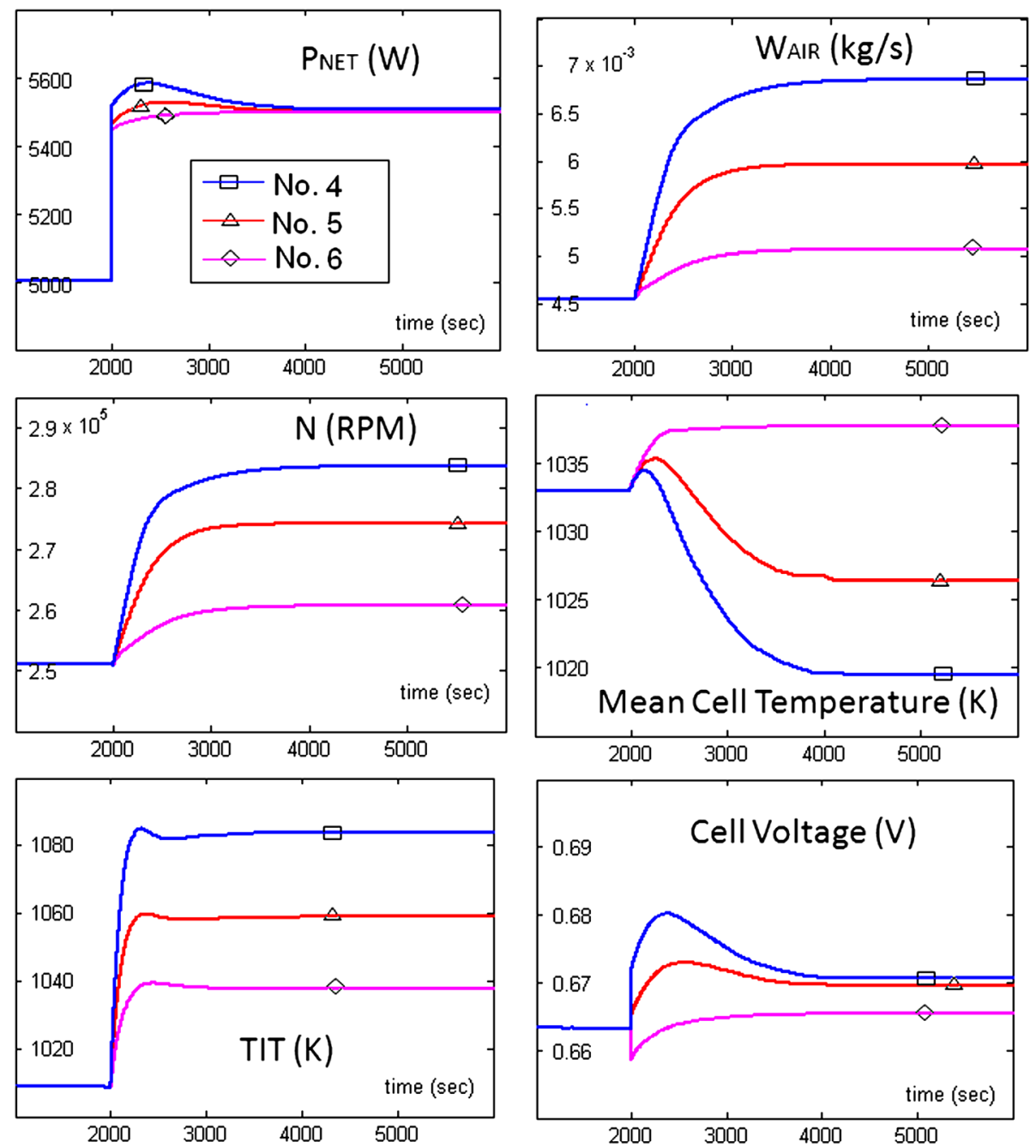

Figure 8. The power responses of dual-shaft SOFC/mGT under control input combinations (Nos. 4-6) in Table VI.

Table VI. Load change scenario: dual-Shaft SOFC/mGT system.

\begin{tabular}{lllll}
\hline No & \multicolumn{1}{c}{$W_{\text {Fuel }}$} & \multicolumn{1}{c}{$I_{\text {COM }}$} & $P_{\text {GEN }}$ & $\eta$ \\
\hline 1 & $1.9 e^{-3}+\Delta W_{100 \%}$ & $2000+\Delta I_{40 \%}$ & 250 & 37.5 \\
2 & $1.9 e^{-3}+\Delta W_{27 \%}$ & $2000+\Delta I_{75 \%}$ & 38.5 \\
3 & $1.9 e^{-3}+\Delta W_{0 \%}$ & $2000+\Delta l_{100 \%}$ & 250 & 39.3 \\
& $W_{\text {Fuel }}$ & $P_{G E N}$ & 250 & 37.4 \\
4 & $1.9 e^{-3}+\Delta W_{80}$ & $250+\Delta P_{G E N, 35 \%}$ & $I_{C O M}$ & 38.4 \\
5 & $1.9 e^{-3}+\Delta W_{40 \%}$ & $250+\Delta P_{G E N, 53 \%}$ & 2000 & 38.9 \\
6 & $1.9 e^{-3}+\Delta W_{0} \%$ & $250+\Delta P_{G E N, 100 \%}$ & 2000 & 2000 \\
\hline
\end{tabular}

\section{OPTIMAL OPERATING STRATEGY FOR A FAST LOAD CHANGE}

Motivated by the observations on the transient loadfollowing characteristics made in the previous section, a novel load-following strategy is developed to achieve the fast load following. In particular, we formulate an optimization problem whose solution will identify optimal operating points that provides proper trade-off between high system efficiency and fast load-following response. The proposed approach allows the designer to quantify the trade-offs between two competing requirements and make the appropriate decision to meet different specifications. 
In order to reflect the effect of the SOFC temperature on transient load operation, we define a cost function as

$$
J=\eta^{-1}+\alpha f\left(T-T_{S E T}\right),
$$

which consists of two parts: an efficiency and the penalty function of a SOFC temperature variation. Here, $\mathrm{T}_{S E T}$ is a desired SOFC temperature, $\alpha$ is a weighting parameter and $f(\cdot)$ is a non-negative monotonic function of $\left|T-T_{S E T}\right|$. Note that the penalty function $f\left(T-T_{S E T}\right)$ can take various forms, for example $f\left(T-T_{S E T}\right)=\left(T-T_{S E T}\right)^{2}$ or $\left|T-T_{S E T}\right|$. For this application, since the analytical solution or gradient-based optimization algorithms are difficult to implement due to non-analytical form of the turbine/compressor models, we use grid-based algorithm for optimization using repeated simulations. In this case, continuity of the derivative is not required for the cost function. Therefore, we choose $f\left(T-T_{S E T}\right)=\left|T-T_{S E T}\right|$ in this work.

To properly define $T_{S E T}$, we take $N$ different load points, and for each point, we find optimal condition under which the efficiency is maximized. Let $T_{i}^{*}$ be the spatial average PEN temperature of these $N$ points, we choose

$$
T_{S E T}=\frac{1}{N} \sum_{i=1}^{N} T_{i}^{*} .
$$

For the cost function defined in (15), we formulate the corresponding optimization problem as:

$$
\begin{aligned}
& \min _{\mathrm{W}_{\text {Fuel }}, \mathrm{I}_{C O M}, \mathrm{P}_{G E N}} \mathrm{~J}, \\
& \text { subject to } P_{\text {NET }}=P_{S E T},
\end{aligned}
$$

where $\mathrm{P}_{S E T}$ is a desired output power.

The optimization problem for (17) can be performed for each power set point. Varying the weighting factor $\alpha$ will lead to different trade-off between achieving maximum steady-state efficiency and fast load transient response.
For example $\alpha=0$ will lead to the control input setting that achieves optimal efficiency. As $\alpha$ increases, more emphasis is placed on maintaining a constant temperature at different load operating points to ease the temperature transition.

\subsection{Single-shaft SOFC/mGT case}

For the single-shaft system, we solved the optimization problem defined by (17) for each load condition and for several different $\alpha$ values. Figure 9(a) shows the resulting system efficiency versus the net power, while Figure 9(b) shows the cell temperature. With $\alpha=0$, we achieve the highest efficiency. As $\alpha$ increases, the efficiency degrades, but the cell temperature profile tends to get closer to the set temperature, reflecting the fact that more emphasis is placed on transitional performance. For example, for a net power of $P_{N E T}=6 \mathrm{~kW}$, the system efficiency drops from $\eta=41.5$ to $\eta=40.5$ and the cell PEN temperature is changed from $1056 \mathrm{~K}$ to $1036 \mathrm{~K}$ as $\alpha$ increases from 0 to 0.4 . Note that the variation of a cell temperature over the power range can be reduced by sacrificing the steady-state optimal efficiency, in exchange for a fast load transient.

Figure 10(a) demonstrates the times required to reach 98\% of the target power when the power command is switched from $P_{A}=5.3 \mathrm{~kW}$ to $P_{B}=5.6 / 5.7 / 6.0 \mathrm{~kW}$. The settling time decreases as $\alpha$ increases. This implies that the proposed load change algorithm is capable of a fast load change. Figure 10(b) shows the time responses of the net power to the step change in the load demand. The results of simulation illustrate the utility of the optimal operating strategy to achieve the fast load change demand. The settling time is significantly shortened from $T_{\alpha=0}=600 \mathrm{~s} T_{\alpha=0.4}=300 \mathrm{~s}$ at the cost of the reduction in the system efficiency by $0.5 \%$ $\left(\eta_{\alpha=0}=41.8 \%\right.$ to $\left.\eta_{\alpha=0.4}=41.3 \%\right)$. The temperature reduction of $30{ }^{\circ} \mathrm{C}$ has taken place as shown in Figure 10(c). The small cell temperature variation with $\alpha=0.4$ resulted in the faster transient response. The result is consistent with the observation made by the sensitivity studies in Section 5 .
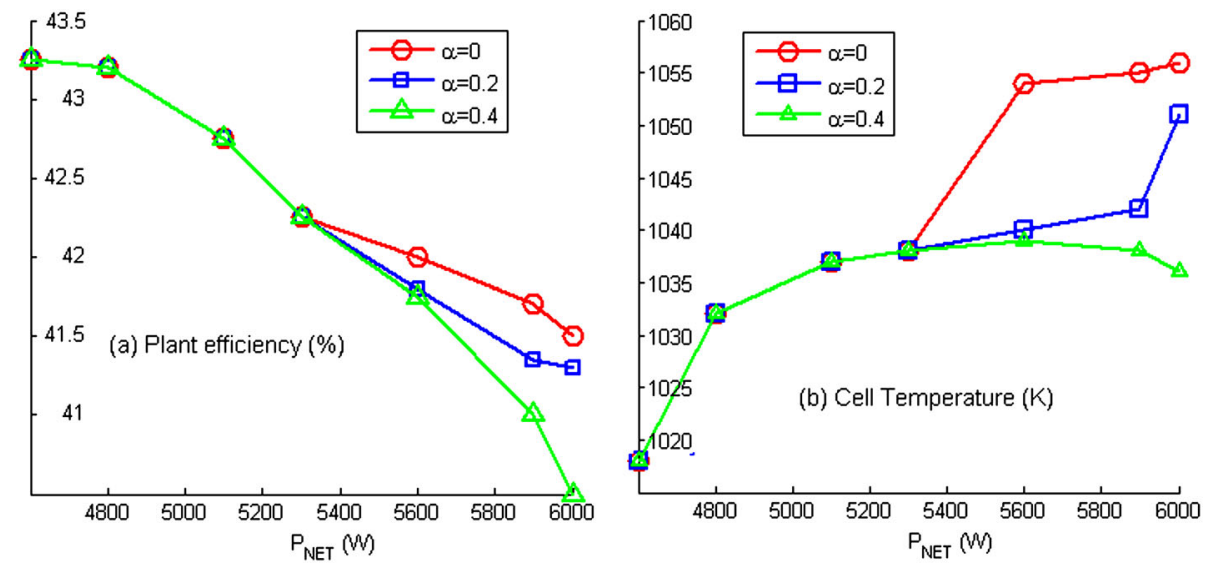

Figure 9. (a) The efficiency as a function of the system net power PNET and $\alpha$ and (b) the corresponding mean PEN temperature. The efficiency decreases as $\alpha$ increases while the cell temperature becomes more flat around the set temperature TSET $=1038 \mathrm{~K}$. 


\subsection{Dual-shaft SOFC/mGT case}

The load change strategy is also explored for the dual-shaft SOFC/mGT hybrid system by solving the same optimization problem (17). Figure 11 shows the system efficiency and the temperature variations over $\alpha=\left[\begin{array}{ll}0 & 0.6\end{array}\right]$ and the corresponding inputs. The similar observations can be made, i.e. the temperature tends to approach the set point temperature $T_{S E T}=1037 \mathrm{~K}$ as $\alpha$ increases from 0 to 0.6 . Note that the increase in $\alpha$ means that the system operates

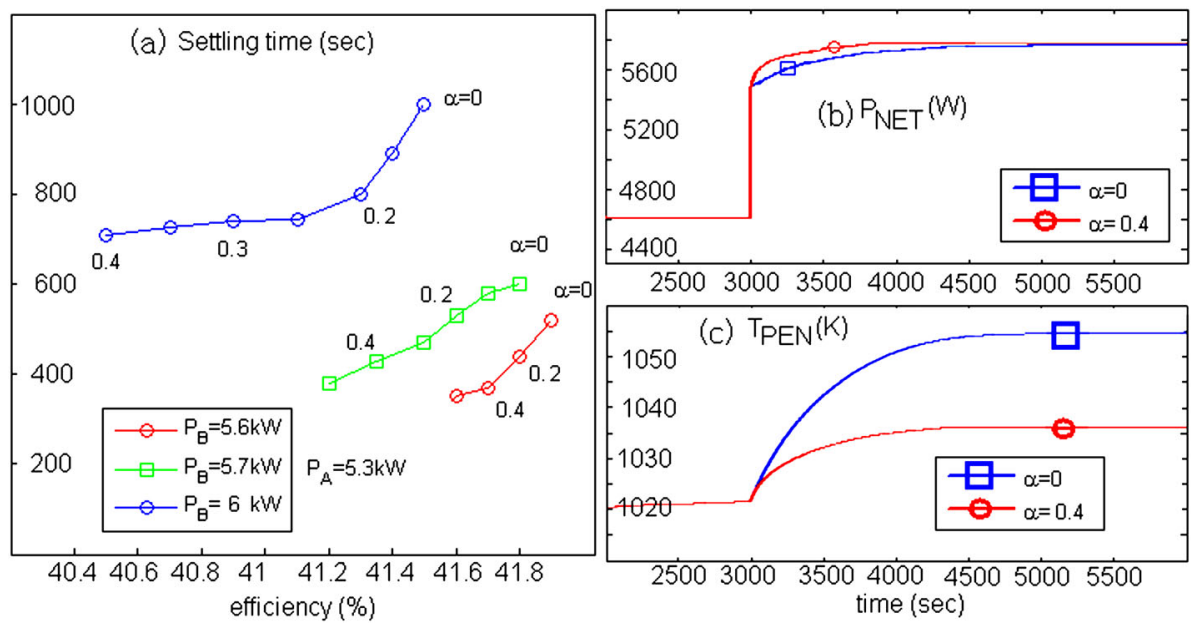

Figure 10. (a) The settling time versus $\alpha$. The suboptimal operating condition can lead to the fast load change. (b/c) The transient net power/temperature response to the step load change from PNET $=4.6 \mathrm{~kW}$ to PNET $=5.77 \mathrm{~kW}$ for the optimal $(\alpha=0)$ and nonoptimal condition ( $\alpha=0.4)$.
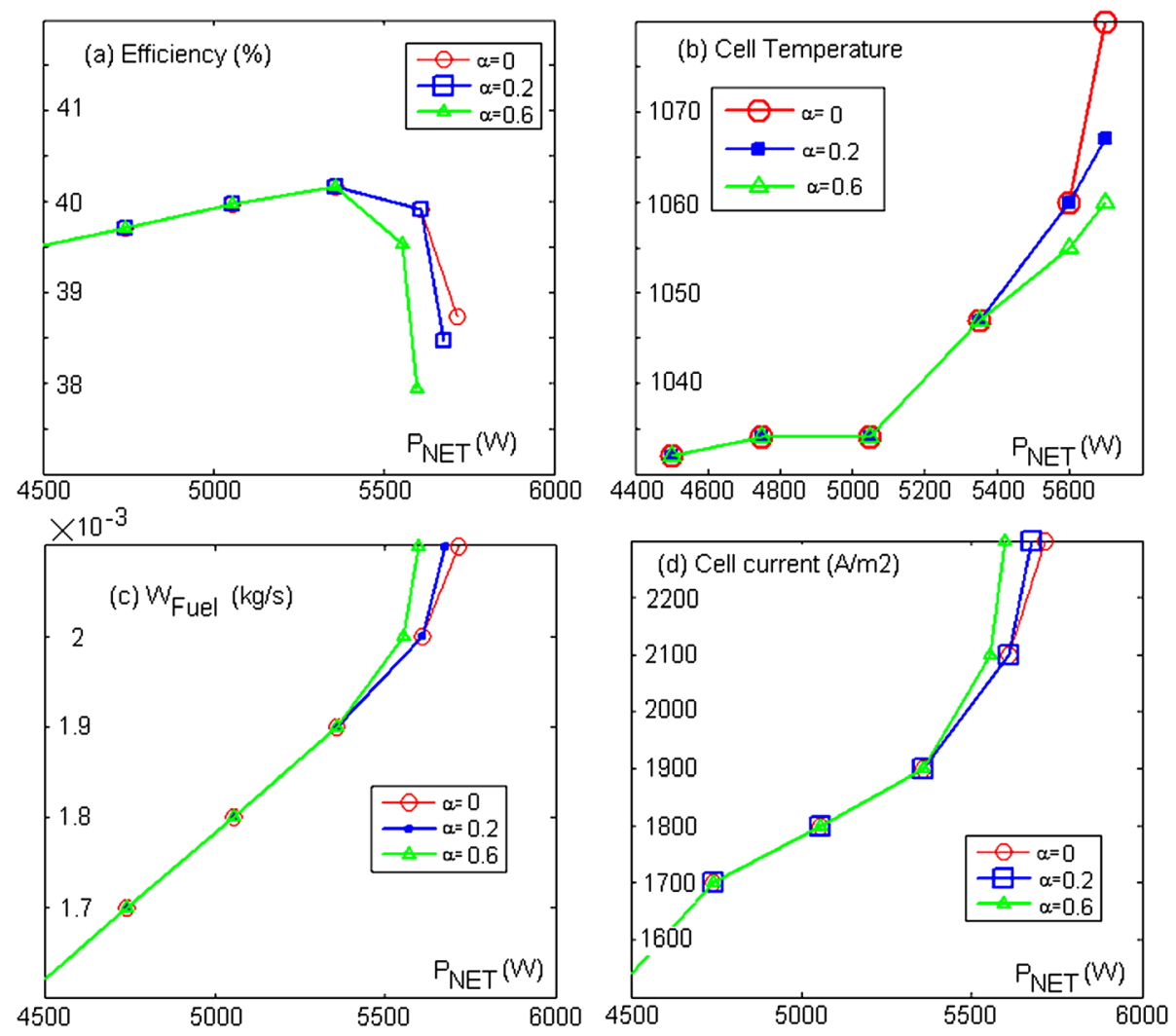

Figure 11. (a/b) The efficiency/cell mean temperature as functions of PNET for different $\alpha$. (c/d) Control inputs (inlet fuel flow WFuel and the current demand ICOM as functions of PNET for different $\alpha$. 


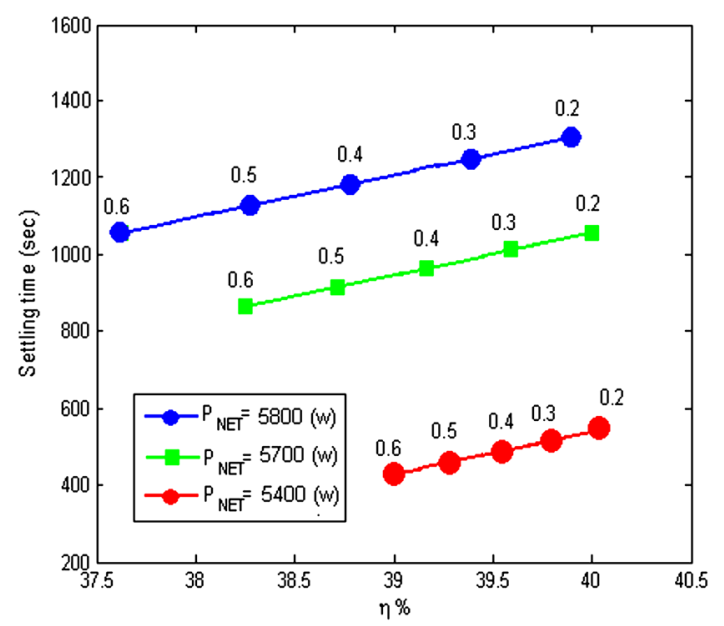

Figure 12. The trade-off between settling time and efficiency as $\alpha$ varies. The values are derived for step load changes from PNET $=5.35 \mathrm{~kW}$ to $\mathrm{PNET}=5.4,5.7,5.8 \mathrm{~kW}$.

at less than its maximum efficiency. However, the increase in $\alpha$ can result in the decrease in the settling time during the load change as shown in Figure 12.

\section{CONCLUSIONS}

Dynamic models of $5 \mathrm{~kW}$ class tubular $\mathrm{SOFC} / \mathrm{mGT}$ hybrids (single/dual-shaft SOFC/mGTs) have been developed that allow the characterization of load performance and control strategies.

The response characteristics of $\mathrm{SOFC} / \mathrm{mGT}$ hybrid systems for load changes have been identified through model-based simulations under different input combinations. The load-following strategy of using the combined fuel and SOFC current outperforms the case when the fuel alone is used, demonstrating the potential of leveraging multivariable control to achieve fast load following while satisfying operational constraints such as the maximum cell temperature. In addition, a computational framework which leads to an optimal load change strategy to achieve the fast load following has been established. Through case studies of step load change for both single- and dual-shaft SOFC/mGT systems, the technique has proven very useful as a mathematical tool in providing quantitative assessments that allow design trade-off between the system efficiency and the fast load-following capability.

\section{NOMENCLATURE}

$C_{(\cdot)} \quad=$ Concentration of species $(\cdot)\left(\mathrm{mol} / \mathrm{m}^{3}\right)$.

$c_{P} \quad=$ Heat capacity $(\mathrm{J} / \mathrm{kg} \cdot \mathrm{K})$.

$d_{f} / a=$ Hydraulic diameter of the fuel/air channel.

$d_{I N J} \quad=$ Diameter of the injection tube.

$D e_{f f} \quad=$ Effective diffusion coefficient.

$F \quad=$ Faraday's constant $(\mathrm{C} / \mathrm{mol})$.

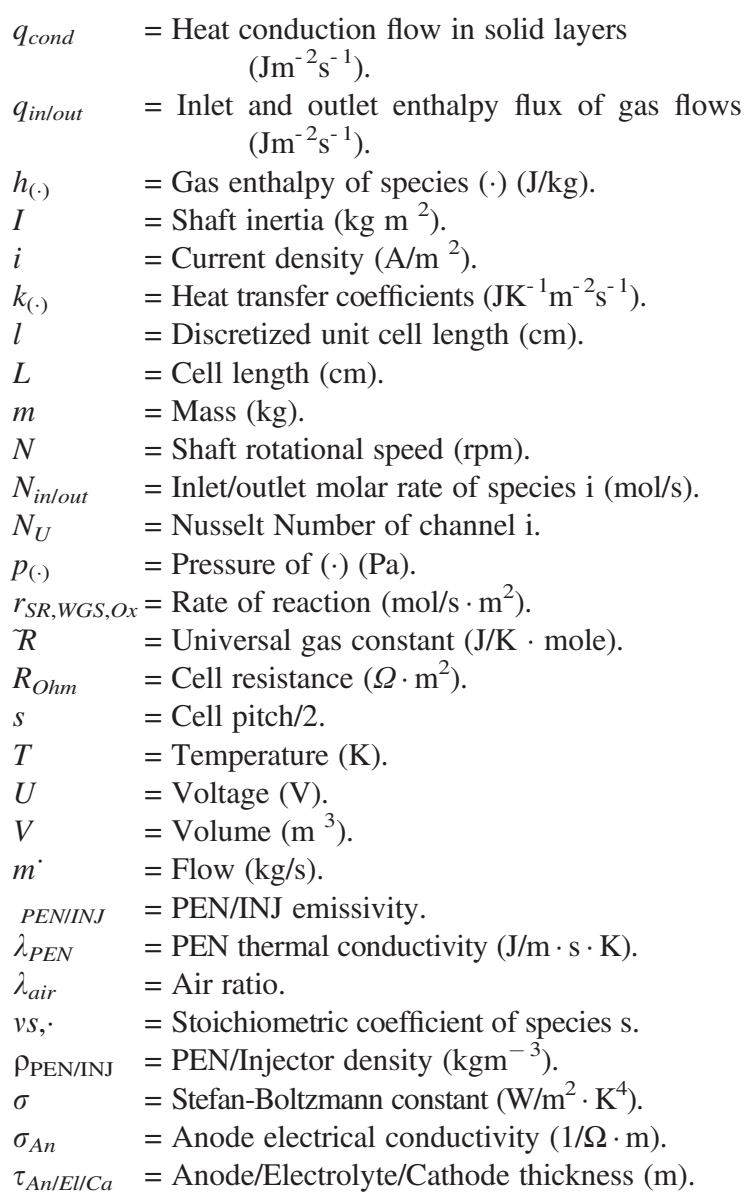

\section{ACKNOWLEDGEMENTS}

This work is funded in part by U.S. Army TARDEC and U.S. Navy (N 655-4010-C-003, Naval Engineering Education Center).

\section{REFERENCES}

1. EG\&G Technical Services, Inc. Fuel Cell Handbook (Seventh). 2004.

2. Larminie J, Dicks A. Fuel Cell System Explained. John Wiley and Sons Ltd 2004.

3. Singhal SC, Kendall K. High Temperature Solid Oxide Fuel CellsOh. Elsevier, 2003.

4. Campanari S. Power Plants based on solid oxide fuel cells combined with gas turbine cycles. Ph.D: Dissertation, 1998.

5. Palsson A, Selimovic A, Sjunnesson L. Combined Solid Oxide Fuel Cell and Gas Turbine Systems for Efficient Power and Heat Generation. J Power Sources 2000; 86:442-448. 
6. Roberts RA, Brouwer J, Jabbari F, Junker T, GhezelAyagh H. Control design of an atmospheric solid oxide fuel cell/gas turbine hybrid system: Variable versus fixed speed gas turbine operation. J Power Sources 2006; 161:484-491.

7. Roberts RA, Brouwer J. Dynamic Simulation of a pressurized 220kW Solid oxide fuel-cell gas-turbine hybrid system: Modeled performance compared to measured results. J Power Sources 2006; 3:18-25.

8. Tucker D., Lawson L., Gemmen R.. Evaluation of Hybrid Fuel Cell Turbine System Startup With Compressor Bleed. ASME Turbo Expo, 2005; GT2005-68784.

9. Ferrari M.L., Pascenti M., Bertone R., Magistri L. Hybrid Simulation Facility Based on Commercial 100kW Micro Gas Turbine. ASME Journal of Fuel Cell Science and Technology, 2009; Vol. 6, 031008:1-8.

10. Panne T., Widenhorn A., Aigner M. Steady State Analysis of A SOFC/GT Hybrid Power Plant Test Rig. Proceedings of ASME Turbo Expo, 2008; GT2008-50288.

11. Tsourapas V. Control analysis of integrated fuel cell systems with energy recuperation devices. In Ph.D. Thesis. University of Michigan, 2007.

12. Wchter C, Lunderstdt R, Joos F. Dynamic model of a pressurized sofc/gas turbine hybrid power plant for the development of control concepts. Journal of Fuel Cell Science and Technology 2006; 3:271-279.
13. Xi H. Dynamic modeling and conrol of planar sofc power systems. In Ph.D. Thesis. University of Michigan, 2007.

14. Achenbach E, Riensche E. Methane steam reforming kinetics for solid oxide fuel cells. J Power Sources 1994; 52(2):283-288.

15. Padulles J, Ault GW, McDonald JR. An integrated SOFC plant dynamic model for power systems simulation. J Power Sources 2000; 86:495-500.

16. Aguiar P, Adjiman CS, Brandon NP. Anode-supported intermediate temperature direct internal reforming solid oxide fuel cell. I: Model-based steady-state performance. J Power Sources 2004; 138:120-136.

17. Hall DJ. Transient Modeling and Simulation of a Solid Oxide Fuel Cell. In Ph.D. Dissertation. University of Pittsburgh, 1997.

18. Stiller C, Thorud B, Seljebo S, Mathisen O, Karoliussen $\mathrm{H}$, Bolland $\mathrm{O}$. Finite-volume modeling and hybrid-cycle performance of planar and tubular solid oxide fuel cells. J Power Sources 2005; 141:227-240.

19. Stiller C, Thorud B, Bolland O. Safe Dynamic Operation of a Simple SOFC/GT Hybrid System. In Proc. of GT2005, ASME Turbo Expo 2005: Power for Land. Sea and Air: Nevada, USA, 2005.

20. Oh S.-R., Sun J., Dobbs H., King J. Comparative Performance Assessment of 5kW-Class Solid Oxide Fuel Cell Engines Integrated with Single/Dual-Spool Turbochargers, 2011 American Control Conference, San Francisco, California, 2011, pp. 5231-5236. 